\title{
ANALISIS JENIS, FUNGSI, MAKNA, DAN NILAI EKONOMI TUMBUHAN PADA RITUAL MAMAPAS LEWU SUKU DAYAK NGAJU
}

\section{ANALYSIS OF PLAN, FUNCTION, MEANING, AND ECONOMIC VALUE OF PLANTS IN THE MAMAPAS LEWU RITUAL DAYAK NGAJU TRIBE}

\author{
Silvia Arianti ${ }^{*}$ \\ Sari Marselina ${ }^{2}$ \\ *I Universitas PGRI Palangka \\ Raya I, Palangka Raya, \\ Indonesia \\ 2 Universitas PGRI Palangka \\ Raya 2, Palangka Raya, \\ Indonesia \\ *email: \\ Silvia.aryanti1985@gmail.com
}

\begin{abstract}
Abstrak
Tumbuhan adalah syarat dalam ritual adat Dayak Ngaju. Setiap tumbuhan yang digunakan memiliki fungsi, makna, dan evaluasi ekonomi dalam pelaksanaan ritual adat Dayak Ngaju. Tujuannya adalah untuk mendeskripsikan gambaran jenis, fungsi, makna, dan nilai ekonomi tumbuhan yang digunakan pada ritual mamapas lewu suku Dayak Ngaju. Metode yang digunakan adalah metode kualitatif dan kuantitatif, data kuantitatif adalah berupa angka yang diperoleh dari hasil penyebaran angket tentang nilai ekonomi tumbuhan yang digunakan dalam ritual mamapas lewu. Teknik pengumpulan data dalam penelitian ini menggunakan teknik observasi, wawancara, rekaman informasi secara lisan dan penyebaran angket. Terdapat 12 tumbuhan yang digunakan dalam ritual mamapas lewu yaitu tangkawang Papas, sawang belum, sawang gagar, sukup/manggis, sukun, pilang, taberau hanyi, kajunjung, kelapa, bambu, sirih, pinang. Fungsi tumbuhan diantara lain yaitu tangkawang Papas, sawang belum, sawang gagar, sukup/manggis, sukun, pilang, taberau hanyi, kajunjung digunakan untuk sebagai bahan papas (sapu) untuk ritual mamapas lewu. Sirih dan pinang memiliki fungsi sebagai pelengkap isi dalam sangku. Makna dari tumbuhan yaitu, sebagai lambang kesejahteraan, kebaikan, keselamatan, rejeki yang banyak, kesehatan, jauh bala, kerukunan, dan persembahan untuk leluhur. Dari 32 orang responden Sukup/manggis $9,38 \%$, pilang $51,13 \%$, dan $21,87 \%$ kajunjung adalah tumbuhan yang susah untuk didapatkan sedangkan tumbuhan lainnya mudah untuk didapatkan. Nilai ekonomi cukup tinggi yaitu dari tumbuhan pilang, sukup/manggis, kajunjung karena tumbuhan ini termasuk tumbuhan yang hanya ada di hutan bukan di sekitar pekarangan masyarakat seperti tumbuhan lainnya. Artinya, nilai ekonomi tumbuhan yang digunakan dalam ritual mamapas lewu dinilai berdasarkan mudah dan banyaknya populasi tumbuhan ini sendiri.
\end{abstract}

\footnotetext{
Kata Kunci:

Tumbuhan,

Mamapas Lewu,

Dayak Ngaju.

Keywords:

Plants,

Mamapas Lewu,

Dayak Ngaju.
}

\begin{abstract}
Plants are a requirement in traditional Dayak Ngaju rituals. Each plant that is used has the function, meaning, and economic value in carrying out traditional Ngaju Dayak rituals. The aim of this research is to describe the description of the types, functions, meanings, and economic value of plants used in the ritual of mamapas lewu Dayak Ngaju tribe. The method used is qualitative and quantitative methods, quantitative data is in the form of numbers obtained from the results of the distribution of questionnaires about the economic value of plants used in the mamapas lewu ritual. Data collection techniques in this study used observation, interviews, recorded information verbally and questionnaires. There are 12 plants used in the mamapas lewu ritual, namely Tangkawang Papas, sawang belum, sawang gagar, sadap / mangosteen, breadfruit, pilang, taberau hanyi, kajunjung, coconut, bamboo, betel, areca nut. Among other plant functions, namely Tangkawang Papas, sawang yet, sawang gagar, sadap / mangosteen, breadfruit, pilang, taberau hanyi, kajunjung are used as ingredients for papas (broom) for the mamapas lewu ritual. Betel and betel nuts have a function as a complement to the contents in sangku. The meaning of plants isas a symbol of well-being, goodness, safety, a lot of fortune, health, far from reinforcements, harmony, and offerings to ancestors. Out of 32 respondents, sukup/mangosteen $9,38 \%$, pilang $51.13 \%$, and $21.87 \%$ kajunjung are plants that are difficult to obtain while other plants are easy to obtain. The economic value is quite high, namely from pilang plants, mangosteen, kajunjung because these plants include plants that only exist in the forest not around the community's yard like other plants. That is, the economic value of plants used in the mamapas lewu ritual is valued on the basis of the ease and size of the plant population itself.
\end{abstract}

(c) yearThe Authors. Published by Institute for Research and Community Services Universitas Muhammadiyah Palangkaraya. This is Open Access article under the CC-BY-SA License (http://creativecommons.org/licenses/by-sa/4.0/). DOI: https://doi.org/10.33084/anterior.v18i2.456. 


\section{PENDAHULUAN}

Setiap upacara adat (tradisional) umumnya berlandaskan pada suatu kepercayaan masyarakat tertentu. Semua berawal pada keyakinan bahwa setiap makhluk ciptaan Tuhan yang ada di dunia ini (termasuk flora dan fauna) memiliki roh dan tempat pengusaannya. Dalam suatu lingkungan tertentu (desa, daerah, regional, aliran sungai, dan sebagainya) memiliki penguasa yang diyakini sebagai roh leluhur yang tidak mau beranjak jauh dari lingkungan keturunannya. Sambil menunggu nafirihari kebangkitan menghadapi pengadilan Tuhan, roh leluhur tersebut masih merasa bertanggung jawab melindungi dan mengayomi keturunannya, dengan menghuni teluk, muara sungai, tepi hutan, dan gundukan batu (Nunun, 2013:1). Melalui kekuatan supranatural komunikasi dua arah dapat berlangsung. Oleh sebab itu upacara adat ritual pada umumnya adalah salah satu wujud komunikasi antara manusia (supranatural) dengan roh-roh penguasa atau roh leluhur.

Dalam pelaksanaan ritual adat, diperlukan perlengkapan yang digunakan untuk pelaksanaan ritual tersebut, baik berupa tumbuhan, makanan, maupun perkakas lainnya. Dalam konsep kaharingan, hutan tidak bisa hilang, karena ketergantungan akan hutan sangat erat sekali dalam kehidupan sehari-hari dalam pelaksanaan ritual adat keagamaan, bagi masyarakat Dayak Ngaju, hutan menyediakan kebutuhan untuk kegiatan ritual adat. Contohnya upacara adat Tiwah, untuk mendirikan balai nyahu (tempat menggantung gerantung/gong) memerlukan kayu, bamboo, tongkat, dan lantai tempat pelaksanaan juga memerlukan bahan dari hutan, atap dari daun silar, yaitu tumbuhan yang dimanfaatkan untuk atai balai. Sandung dibuat juga dari kayu khusus seperti tabalien (ulin). Alternatif kayu lain pengganti kayu tabalien adalah kayu teras tampang, kahuy, dan kalapapa. Jika smapai kayu digunakan digunakan menandakan bahwa kayu ulin tadi sudah langka atau punah (Batuallo, 2015:34)
Ada tumbuhan yang sulit atau mulai langka dididapatkan untuk keperluan ritual adat. Ketersediaan dan kelangkaan sumber daya alam menjadi salah satu sebab tumbuhan hutan yang tadinya tidak memilki nilai ekonomi jadi memilki nilai ekonomi karena rasa ingin membayar. Secara formal, konsep ini disebut keinginan membayar atau willingness to pay (WTP) seseorang terhadap barang dan jasa yang dihasilkan oleh sumber daya alam dan lingkungan. Dengan menggunakan pengukuran ini, nilai ekologis ekosistem bisa diterjemahkan ke dalam bahasa ekonomi dengan mengukur nilai moneter barang dan jasa. Keinginan membayar juga dapat diukur dalam bentuk kenaikan pendapatan yang menyebabkan seseorang berada dalam posisi indifferent terhadap perubahan eksogenous. Tumbuhan menjadi syarat dalam ritual adat Dayak Ngaju.

Setiap tumbuhan yang digunakan memiliki fungsi, makna, dan evaluasi ekonomi dalam pelaksanaan ritual adat Dayak Ngaju. Tumbuhan yang digunakan dalam setiap ritual adat pun berbeda-beda. Hal inilah yang menjadi fokus dalam penelitian ini, sehingga penelitian yang berjudul "Analisis Jenis, Fungsi, Makna, dan Nilai Ekonomi Tumbuhan pada Ritual Mamapas Lewu Suku Dayak Ngaju". Tujuan penelitian ini adalah mendiskripsikan gambaran jenis, fungsi, makna, dan nilai ekonomi tumbuhan yang digunakan pada ritual mamapas lewu suku Dayak Ngaju. Bagi Suku Dayak dalam hal ini suku Dayak Ngaju, antara ritual dan gejala-gejala alam sekitar memiliki keterkaitan satu dengan yang lain. Hal ini sangat jelas terlihat apabila ada ketidakseimbangan alam, maka oleh suku Dayak Ngaju yang masih menganut agama kaharingan. Agama merupakan keyakinan terhadap sesuatu yang spiritual. Esensi setiap agama, seperti juga mitologi adalah animisme, yaitu kepercayaan terhadap sesuatu yang hidup dan punya kekuatan. Animism adalah bentuk pemikiran yang paling tua, yang dapat ditemukan dalam setiap sejarah kehidupan manusia (Pals, 2016:4I). 
Ritual adalah serangkaian kegiatan yang dilaksanakan terutama untuk tujuan simbolis. Ritual dilaksanakan berdasarkan suatu agama atau bisa juga berdasarkan tradisi dari suatu komunitas tertentu. Kegiatan-kegiatan dalam ritual biasanya sudah diatur dan ditentukan, dan tidak dapat dilaksanakan secara sembarangan. Agama dan ritual memilki keterkaitan, dengan kata lain bahwa ritual merupakan agama dalam tindakan.

Ritual berfungsi sebagai aktivitas untuk menimbulkan kembali semangat kehidupan social dalam tiap masyarakat di dunia secara berulang, dengan interval waktu tertentu, memerluak hal yang disebut regenerasi semangat kehidupan sosial seperti itu. Hal itu disebabkan karena selalu ada saat-saat di mana semangat kehidupan social menurun dan akibatnya kan timbul kelesuan dalam masyarakat.

Upacara Manyanggar atau mamapas lewu merupakan salah satu jenis upacara yang dilaksanakan oleh masyarakat Hindu Kaharingan. Upacara Manyanggar atau mamapas lewu dilaksanakan untuk mengucapkan terima Kasih kepada Ranying Hatalla serta roh suci leluhur karena beliau telah menjaga dan memberikan keselamatan kepada masyarakat yang tinggal di kampung tersebut. Upacara dipimpin oleh tiga orang Rohaniwan yang disebut Tukang Rukun/ Basir. Pelaksana upacara melibatkan seluruh masyarakat bergabung secara gotong royong bersamasama menjalin kerja sama menjunjung tinggi asas kekeluargaan maupun musyawarah mufakat mulai dari mempersiapkan sarana sampai proses terselenggaranya upacara manyanggar mamapas lewu (Ratini, 2015: 2 Vol 5 No. 2).

$$
\text { Upacara manyanggar mamapas lewu }
$$
bermakna untuk membersihkan/menetralisir kekuatan yang disebabkan oleh pengaruh makhluk gaib yang bersifat negatif yang dapat mengancam keselamatan warga masyarakat di kampung tempat mereka tinggal. Sehingga terjaga keseimbangan dan keharmonisan hidup. Sesuai dengan konsep ajaran Tri Hita Karana yaitu Menjaga keharmonisan dengan Tuhan Yang Maha Esa (Ranying Hatalla Langit) sebagai sumber segala yang ada di dunia ini, Menjaga keharmonisan dengan sesama manusia karena manusia selalu membutuhkan orang lain untuk hidup dan menjaga keharmonisan dengan alam Lingkungan sekitarnya. Dengan terwujudnya keseimbangan berarti terwujud pula keharmonisan hidup yang didambakan oleh setiap orang di dunia ini (Batuallo, 2015: 49).

Pengertian nilai atau value, khususnya yang menyangkut barang dan jasa yang dihasilkan oleh sumber daya alam dan lingkungan memang bisa berbeda jika dipandang dari berbagai disiplin ilmu, karena itu diperlukan suatu persepsi yang sama untuk penilaian ekosistem tersebut. Salah satu tolak ukur yang relatif mudah dan bisa dijadikan persepsi bersama berbagai disiplin ilmu tersebut adalah pemberian price tag (harga) pada barang dan jasa yang dihasilkan sumber daya alam dan lingkungan. Dengan demikian, kita menggunakan apa yang disebut nilai ekonomi sumber daya alam (Yakin, 2016:4I).

Secara umum, nilai ekonomi didefinisikan sebagai pengukuran jumlah maksimum seseorang ingin mengorbankan barang dan jasa untuk memperoleh barang dan jasa lainnya. Secara formal, konsep ini disebut keinginan membayar atau willingness to pay (WTP) seseorang terhadap barang dan jasa yang dihasilkan oleh sumber daya alam dan lingkungan. Dengan menggunakan pengukuran ini, nilai ekologis ekosistem bisa diterjemahkan ke dalam bahasa ekonomi dengan mengukur nilai moneter barang dan jasa. Keinginan membayar juga dapat diukur dalam bentuk kenaikan pendapatan yang menyebabkan seseorang berada dalam posisi indifferent terhadap perubahan eksogenous.Perubahan eksogenous ini bisa terjadi karena perubahan harga (misalnya akibat sumber daya makin langka) atau karena perubahan kualitas sumber daya. Dengan demikian konsep WTP ini terkait erat dengan konsep Compensating Variation dan Equivalent Variation dalam teori permintaan. WTP 
dapat juga diartikan sebagai jumlah maksimal yang seseorang bersedia bayarkan untuk menghindari terjadinya penurunan terhadap sesuatu.

Selain dari pengukuran nilai ekonomi dapat juga dilakukan melalui pengukuran kesediaan menerima atau willingness to accept (WTA) yang tidak lain dalah jumlah minimum pendapatan seseorang untuk mau menerima penurunan sesuatu. Dalam praktik pengukuran nilai ekonomi, WTP lebih sering digunakan dari pada WTA, karena WTA bukan pengukuran yang berdasarkan insentif (insentive based) sehingga kurang tepat untuk dijadikan studi yang berbasis perilaku manusia.

Lingkungan budaya masyarakat tradisional kaya akan kearifan lokal, namun belum banyak diungkap bagaimana kearifan ini tumbuh dan terpelihara dalam kehidupan masyarakat tersebut. Diperlukan upaya penggalian adat istiadat dan budaya untuk memperkuat basis masyarakat dalam menjaga kebudayaan mereka (Suryansyah, 20II). Suku Melayu masih mengadakan ritual adat yang menggunakan tumbuhan. Sebagai contoh adalah Upacara Adat Tumpang Negeri. Upacara adat Tumpang Negeri merupakan salah satu adat kenegerian Melayu Landak, bermula dari Raja Abdul Kahar pada abad ke-l2. Upacara Adat Tumpang Negeri dilaksanakan setahun sekali, yaitu pada awal atau akhir tahun dengan melihat keadaan alam. Tujuan dilaksanakannya upacara adat ini adalah untuk menolak bala agar masyarakat Landak terhindar dari bahaya dan agar menjadi negeri yang makmur, aman dan damai.

Pemanfaatan tumbuhan dalam upacara adat Tumpang Negeri sebagian besar masih dilakukan oleh masyarakat yang bertempat tinggal di pedesaan. Pemanfaatan tumbuhan berdasarkan cerita atau penuturan secara lisan dari para orang tua zaman dahulu dan diyakini sampai saat ini. Dari hasil wawancara, zaman dulu masyarakat memanfaatkan tumbuhan sebagai pengusir roh-roh jahat. Tumbuhan Padi atau $O$. sativa memiliki makna berdasarkan kepercayaan nenek moyang pada zaman dahulu padi memiliki simbol kerekatan sosial antar individu, dan keselarasan hidup antara manusia dengan alam (Uswatun Hasanah, 2014; 23 vol. 3 No. 3)

\section{METODOLOGI}

Metode yang digunakan dalam penelitian ini adalah metode kualitatif dan kuantitatif, Data kuantitaif dalam penelitian ini berupa angka yang diperoleh dari hasil penyebaran angket tentang nilai ekonomi tumbuhan yang digunakan dalam ritual mamapas lewu.Sumber data dalam penelitian ini adalah informan di lapangan. Informan yang dimaksud dikategorikan sebagai masyarakat Dayak Ngaju yang tinggal dan dipilih sebagai basir adat di Kota Palangka Raya.Teknik pengumpulan data dalam rencana penelitian ini menggunakan teknik observasi, wawancara, rekaman informasi secara lisan dan penyebaran angket.

Penelitian ini menggunakan teknik analisis kualitatif dan analisis kuantitatif.Teknik analisis kualitatif digunakan untuk menganalisis data yang berupa kata, kalimat,atau wacana yang berkaitan dengan aspek yang diteliti. Teknik analisis kuantitatifdigunakan untuk menganalisis data berupa angka-angka yang diperoleh dari jawaban angket yang disebarkan dalam kaitannya tentang nilai ekonomi tumbuhan yang digunakan dalam ritual mamapas lewu. Kedua teknik ini diuraikan sebagai berikut:

I. Teknik analisis data kualitatif ini menggunakan langkah-langkah analisis data yang dirumuskan Reffaterre (dalam Endraswara, 2003:67). Langkahlangkah tersebut adalah sebagai berikut:

a. Memberi deskripsi terhadap masalah yang dihadapi dari setiap data yang diperoleh.

b. Memeriksa sumber data yang tertulis yang mempunyai keterkaitan dengan data yang diteliti.

c. Melakukan analisis terhadap jenis, fungsi, makna tumbuhan yang digunakan dalam ritual mamapas lewu. 
d. Mengadakan peninjauan ulang terhadap hasil analisis.

e. Memberi interpretasi terhadap analisis data.

f. Merumuskan simpulan berdasarkan hasil analisis yang telah diinterpretasi.

g. Memberikan simpulan umum tentang hasil deskripsi dan analisis.

h. Memaparkan hasil penelitian secara lengkap dalam bentuk tertulis.

2. Teknik analisis data kuantitatif dalam penelitian ini menggunakan beberapa tahapan analisis data sebagai berikut:

a. Memeriksa sumber data yang tertulis berkaitan dengan data kuantitatif (data hasil penyebaran angket).

b. Melakukan analisis terhadap data hasil penyebaran angket.

c. Mengadakan peninjauan ulang terhadap hasil analisis yang dilakukan.

d. Memberikan interpretasi terhadap analisis data.

e. Merumuskan simpulan berdasarkan hasil analisis yang telah diinterpretasikan.

f. Memberikan simpulan umum tentang hasil analisis.

g. Memaparkan hasil penelitian dalam bentuk tertulis.Pengujian Keabsahan DataPeneliti menggunkan kriteria keabsahan data, yaitu menggunakan empat kriteria yang digunakan yaitu derajat kepercayaan, keteralihan, ketergantungan, kepastian (Moleong, 2000:12).Teknik pemeriksaan keabsahan data dapat diihat dari beberapa teknik pemeriksaan sebagai berikut.

a. Perpanjangan keikutsertaan

Penelitian sebagai human instrumen ikut dalam pengumpulan data. Keikutsertaan tersebut tidak hanya dalam waktu singkat, tetapi diperlukan perpanjangan keikutsertaan dalam pengumpulan data mengklarifikasikan dan menelaahnya sehingga memungkinkan tingkat kepercayaan terhadap data yang dikumpulkan.

b. Ketekunan pengamatan

Peneliti mengadakan pengamatan dengan teliti dan rinci.

c. Triangulasi

Teknik pemeriksaan keabsahan data yang memanfaatkan sesuatu yang lain di luar data itu untuk keperluan pengecekan atau sebagai pembanding terhadap data itu.

\section{HASIL DAN PEMBAHASAN}

I. Jenis, Fungsi, Makna Tumbuhan pada Ritual Mamapas Lewu

\begin{tabular}{|c|c|c|c|c|c|c|}
\hline No & $\begin{array}{c}\text { Nama } \\
\text { Lokal/ } \\
\text { Indonesia }\end{array}$ & $\begin{array}{c}\text { Bagian } \\
\text { yang } \\
\text { Digunakan }\end{array}$ & Jenis & Fungsi & Makna & Gambar \\
\hline 1 & $\begin{array}{l}\text { Tangkawang } \\
\text { Papas }\end{array}$ & $\begin{array}{l}\text { Daun dan } \\
\text { ranting }\end{array}$ & $\begin{array}{l}\text { Shorea } \\
\text { (kayu- } \\
\text { kayuan) }\end{array}$ & $\begin{array}{l}\text { Sebagai } \\
\text { bahan } \\
\text { papas } \\
\text { (sapu) } \\
\text { untuk } \\
\text { ritual } \\
\text { mamapas } \\
\text { lewu }\end{array}$ & $\begin{array}{l}\text { Dijadikan } \\
\text { lambang } \\
\text { untuk } \\
\text { hidup } \\
\text { yang lebih } \\
\text { baik di } \\
\text { tahun } \\
\text { yang akan } \\
\text { datang. } \\
\text { Dijauhkan } \\
\text { dari } \\
\text { segala } \\
\text { kapapa } \\
\text { belum } \\
\text { (kesialan). }\end{array}$ & \\
\hline 2 & $\begin{array}{l}\text { Sawang } \\
\text { Belum }\end{array}$ & Daun & $\begin{array}{l}\text { Tanama } \\
\mathrm{n} \text { perdu }\end{array}$ & $\begin{array}{l}\text { Sebagai } \\
\text { bahan } \\
\text { papas } \\
\text { (sapu) } \\
\text { untuk } \\
\text { ritual } \\
\text { mamapas } \\
\text { lewu }\end{array}$ & $\begin{array}{l}\text { Sebagai } \\
\text { lambang } \\
\text { keselamat } \\
\text { an bagi } \\
\text { masyarak } \\
\text { at } \\
\text { Kalimanta } \\
\text { n Tengah. } \\
\text { Dijauhkan } \\
\text { dari } \\
\text { segala } \\
\text { penyakit } \\
\text { dan } \\
\text { marabaha } \\
\text { ya. }\end{array}$ & \\
\hline 3 & $\begin{array}{l}\text { Sawang } \\
\text { Gagar }\end{array}$ & Daun & $\begin{array}{l}\text { Tanama } \\
\mathrm{n} \text { perdu }\end{array}$ & $\begin{array}{l}\text { Sebagai } \\
\text { bahan } \\
\text { papas } \\
\text { (sapu) } \\
\text { untuk } \\
\text { ritual } \\
\text { mamapas } \\
\text { lewu }\end{array}$ & $\begin{array}{l}\text { Sebagai } \\
\text { lambang } \\
\text { keselamat } \\
\text { an bagi } \\
\text { masyarak } \\
\text { at } \\
\text { Kalimanta } \\
\text { n Tengah. } \\
\text { Dijauhkan } \\
\text { dari } \\
\text { segala } \\
\text { penyakit } \\
\text { dan } \\
\text { marabaha } \\
\text { ya }\end{array}$ & \\
\hline
\end{tabular}


Silvia Arianti dan Sari Marselina. Analisis Jenis, Fungsi, Makna, dan Nilai Ekonomi Tumbuhan Pada Ritual Mamapas Lewu Suku Dayak Ngaju.

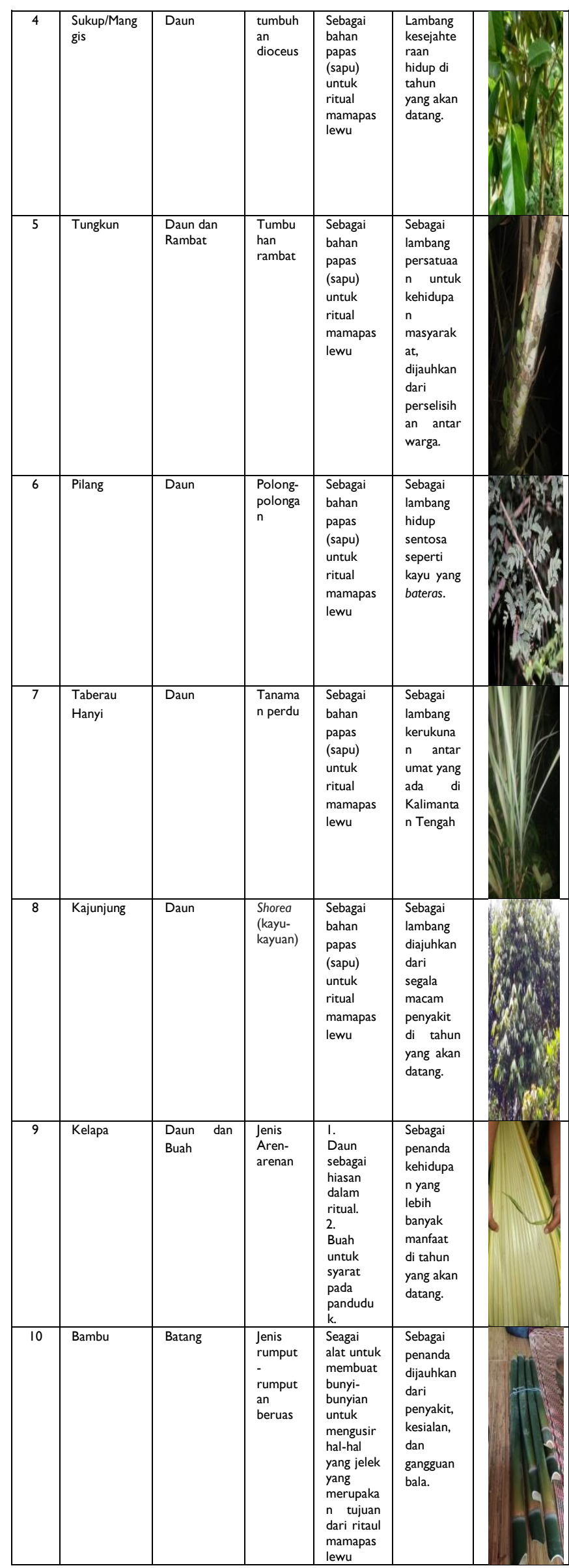

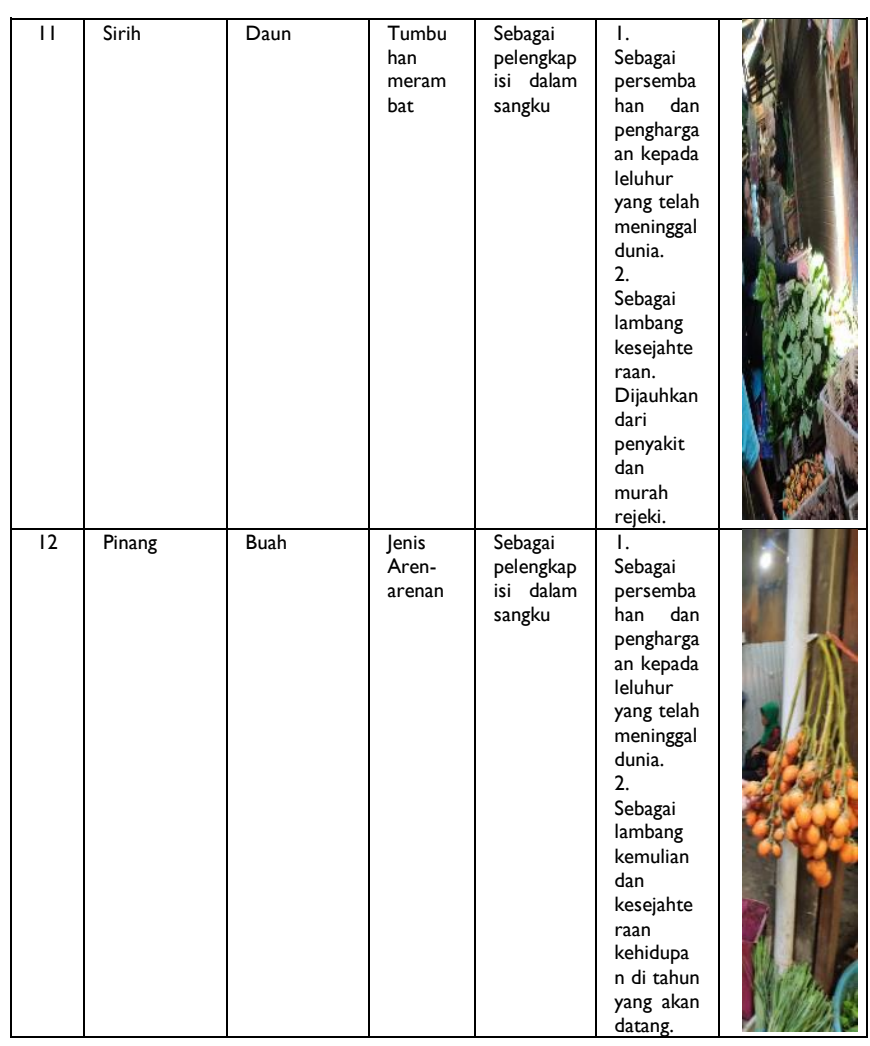

2. Analisis WTP Terhadap Tumbuhan pada Ritual Mamapas Lewu

a. Waktu yang diperlukan untuk menemukan Tumbuhan.

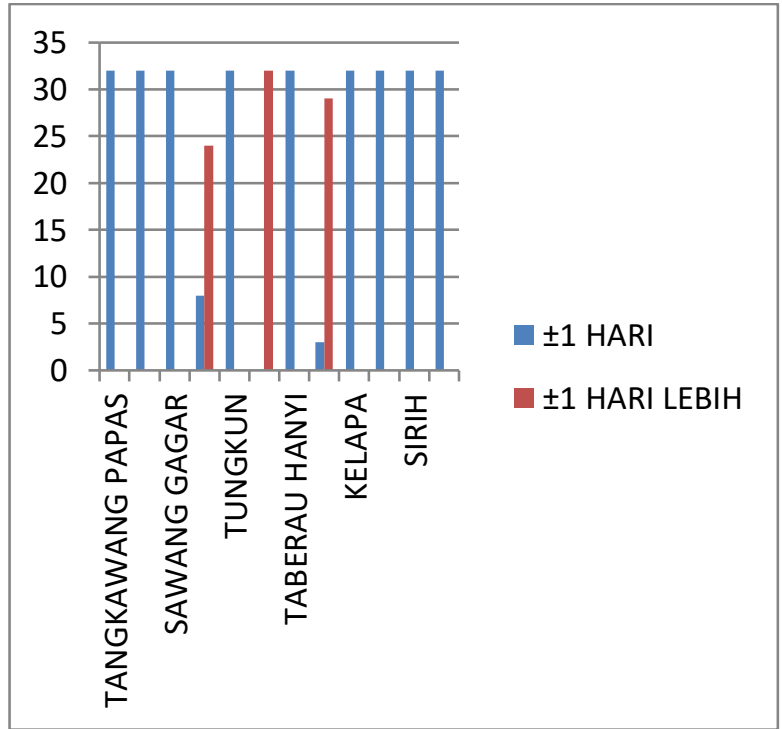

Berdasarkan tabel dapat dilihat bahwa tumbuhan tangkawang papas, sawang belum, sawang gagar,tungkun, taberau hanyi, kelapa, bambu, sirih, pinang adalah tumbuhan yang dapat diperoleh dalam waktu satu hari, sedangkan sukup/manggis, pilang, kajunjung adalah tumbuhan yang memerlukan waktu 
lebih dari satu hari pemerolehannya untuk digunakan dalam ritual mamapas lewu.

b. Proses memperoleh Tumbuhan

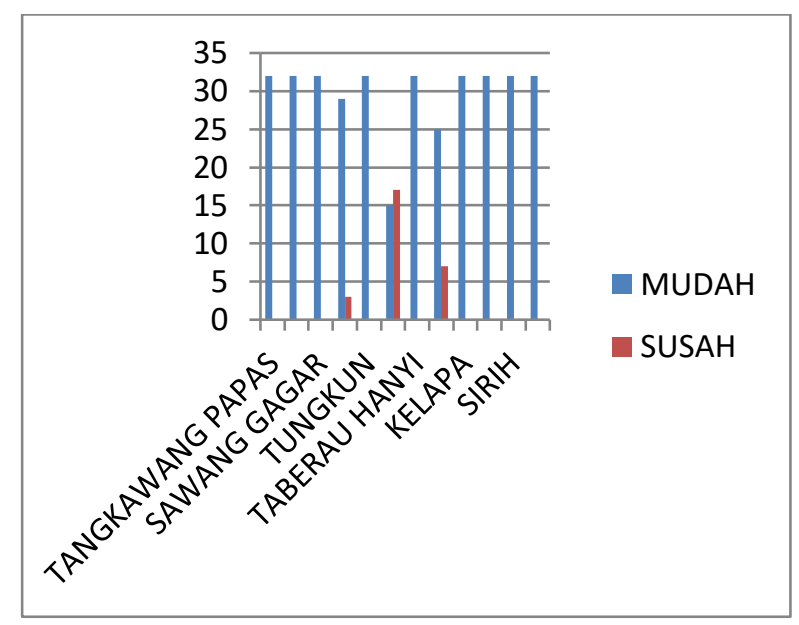

Tumbuhan tangkawang papas, sawang belum, sawang gagar, tungkun, taberau hanyi, kelapa, bambu, sirih dan pinang adalah tumbuhan yang mudah untuk didapatka, sedangkan sukup/manggis $9,38 \%$ responden menjawab susah didapatkan, tumbuhan pilang $5 \mathrm{I}, 13 \%$ responden menjawab susah untuk didapatkan, $21,87 \%$ responden menjawab tumbuhan kajunjung susah untuk didapatkan sebagai keperluan dalam ritual mamapas lewu.

c. Membayar untuk setiap tumbuhan.

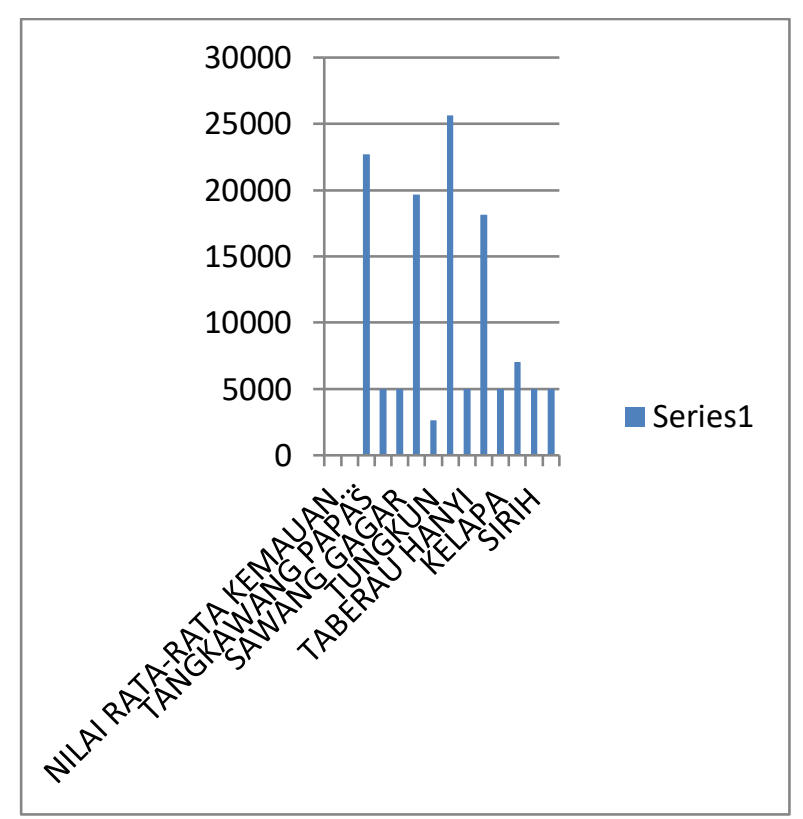

Kedua table di atas menggabarkan nilai ekonomi dari setiap tumbuhan yang digunakan dalam ritual mamapas lewu.Tumbuhan pilang, sukup/manggis, kajunjung merupakan tumbuhan yang memiliki nilai ekonomi cukup tinggi karena tumbuhan ini termasuk tumbuhan yang tumbuhnya di hutan bukan di sekitar pekarangan masyarakat seperti tumbuhan lainnya. Artinya, nilai ekonomi tumbuhan yang digunakan dalam ritual mamapas lewu dinilai berdasarkan mudah dan banyaknya populasi tumbuhan ini sendiri. Sedangkan tumbuhan tangkawang papas memiliki nilai ekonomi tinggi meskipun keberdaannya banyak dan mudah dicaritetap memiliki nilai ekonomi tinggi karena tumbuhan ini merupakan syarat utama dalam ritual mamapas lewu yang tidak bias ditinggal atau digantkan dengan tumbuhan lainnya. Artinya, nilai ekonomi tumbuhan yang digunakan dalam ritual mamapas lewu dinilai berdasarkan mudah dan banyaknya populasi tumbuhan ini sendiri, serta fungsi utama dari tumbuhan tersebut.

\section{KESIMPULAN}

Berdasarkan hasil penelitian di atas dapat disimpulkan sebagai berikut.

I. Terdapat 12 tumbuhan yang digunakan dalam ritual mamapas lewu. Tumbuhan itu yaitu tangkawang Papas, sawang belum, sawang gagar, sukup/manggis, sukun, pilang, taberau hanyi, kajunjung, kelapa, bambo, sirih, pinang.

2. Fungsi tumbuhan diantara lain yaitu tangkawang Papas, sawang belum, sawang gagar, sukup/manggis, sukun, pilang, taberau hanyi, kajunjung digunakan untuk sebagai bahan papas (sapu) untuk ritual mamapas lewu. Sirih dan pinang memiliki fungsi sebagai pelengkap isi dalam sangku.

3. Makna tumbuhan yang digunakan dalam ritual mamapas lewu yaitu, sebagai lambing kesejahteraan, kebaikan, keselamatan, rejeki yang banyak, kesehatan, jauh bala, kerukunan, dan persembahan untuk leluhur.

4. Tumbuhan tangkawang papas, sawang belum, sawang gagar, tungkun, taberau hanyi, kelapa, bambo, sirih, pinang adalah tumbuhan yang dapat 
diperoleh dalam waktu satu hari, sedangkan sukup/manggis, pilang, kajunjung adalah tumbuhan yang memerlukan waktu lebih dari satu hari pemerolehannya untuk digunakan dalam ritual mamapas lewu.

5. Tumbuhan tangkawang papas, sawang belum, sawang gagar, tungkun, taberau hanyi, kelapa, bambu, sirih dan pinang adalah tumbuhan yang mudah untuk didapatkan, sedangkan sukup/manggis $9,38 \%$ responden menjawab susah didapatkan, tumbuhan pilang $5 \mathrm{I}, 13 \%$ responden menjawab susah untuk didapatkan, 21,87\% responden menjawab tumbuhan kajunjung susah untuk didapatkan sebagai keperluan dalam ritual mamapas lewu.

6. Nilai ekonomi dari setiap tumbuhan yang digunakan dalam ritual mamapas lewu. Tumbuhan pilang, sukup/manggis, kajunjung merupakan tumbuhan yang memiliki nilai ekonomi cukup tinggi karena tumbuhan ini termasuk tumbuhan yang tumbuhnya di hutan bukan di sekitar pekarangan masyarakat seperti tumbuhan lainnya. Artinya, nilai ekonomi tumbuhan yang digunakan dalam ritual mamapas lewu dinilai berdasarkan mudah dan banyaknya populasi tumbuhan ini sendiri. Sedangkan tumbuhan tangkawang papas memiliki nilai ekonomi tinggi meskipun keberdaannya banyak dan mudah dicaritetap memiliki nilai ekonomi tinggi karena tumbuhan ini merupakan syarat utama dalam ritual mamapas lewu yang tidak bisa ditinggal atau digantikan dengan tumbuhan lainnya. Artinya, nilai ekonomi tumbuhan yang digunakan dalam ritual mamapas lewu dinilai berdasarkan mudah dan banyaknya populasi tumbuhan ini sendiri, serta fungsi utama dari tumbuhan tersebut.

\section{UCAPAN TERIMA KASIH}

Para penulis menyampaikan terima kasih kepada Kemenntrian Riset Teknologi dan Pendidikan Tinggi
Republik Indonesia yang telah memfasilitasi penelitian ini. Ucapan penghargaan dan terima kasih juga kami haturkan kepada Damang dan Mantir di Kota Palangka Raya yang memberikan banyak ide dan masukan terhadap gagasan awal penelitian yang dilakukan penulis.

\section{REFERENSI}

Nunun. 2013. Upacara Tradisional Daerah Kalimantan Tengah Bagian II. Palangka Raya: Dinas Pendidikan dan Kebudayaan Kalimantan Tengah.

Batuallo, Salmon. 20I5. Peranan Nilai Budaya Masyarakat Dayak Ngaju dalam Memelihara Lingkungan Di Provinsi Kalimantan Tengah. Palangka Raya: Departemen Kebudayaan dan Pariwisata Kalimantan Tengah.

Pals, Daniel L. 2014. Dekonstruksi Kebenaran: Kritik Tujuh Teori Agama. Yogyakarta: IRCiSOD.

Ratini, Ni Made. 2015. Upacara Manyanggar Mamapas Lewu Rantau pulut Kecamayan Seruyan Tengah Kabupaten Seruyan. Jurnal Belom Bahadat, volume 5 (2): 275-287.

Yakin, Adinul. 2016. Ekonomi Sumber Daya Alam dan Lingkungan. Bandung: Adijaya Press.

Hasanah, Uswatun. 2014. Pemanfaatan Tumbuhan pada Upacara Adat Tumpang Negeri Suku Melayu di Keraton Ismahayana Landak. Jurnal Protobiont, volume 3 (3): 17-24

Sugiyono. 2014. Memahami Penelitian Kualitatif. Bandung: CV Alfabeta.

Endraswara, Suwardi. 20II. Metodelogi Penelitian Sosiologi Sastra. Yogyakarta: CAPS.

Moleong, Lexy J. 20I2. Metodelogi Penelitian Kualitatif. Bandung: PT Remaja Rosdakarya. 